\title{
PERAN GENDER DALAM PENINGKATAN KESEJAHTERAAN MASYARAKAT DESA WISATA COLO KABUPATEN KUDUS
}

\author{
Gender in the improvement of Social Welfare \\ in Colo Rural Tourism, Kudus Regency
}

Deny Aditya Puspasari ${ }^{1}$, Sariffuddin ${ }^{2}$

Diterima: 6 Agustus 2015 Disetujui: 15 Oktober 2015

\begin{abstract}
Abstrak: Pengembangan Desa Wisata merupakan model pengembangan pariwisata yang dicanangkan oleh Kementrian Pariwisata dan Ekonomi Kreatif untuk meretas kemiskinan di pedesaan. Hal inilah yang membuat pemerintah Kabupaten Kudus berinisiatif untuk mengembangkan Desa Colo menjadi Desa Wisata yang berbasis wisata alam. Dengan Ketenaran Sunan Muria di Kabupaten Kudus, menjadikan Desa Colo yang terletak di kawasan Pegunungan Muria sebagai salah satu destinasi wisata yang terus berkembang. Melihat potensi ini, masyarakat desa melakukan pengelolaan obyek wisata secara swadaya dan informal melalui pembentukan komunitas-komunitas pendukung pariwisata seperti ojek, pedagang asongan dan pedagang kaki lima. Terdapat fenomena unik yang tedapat di Desa Colo yaitu adanya pengelolaan wisata dengan peran gender. Peran gender tersebut tidak hanya terjadi di dalam peningkatan kesejahteraan. Menjadi menarik untuk diteliti bagaimana peran gender terhadap peningkatan kesejahteraan masyarakat desa wisata Colo ? untuk menjawab pertanyaan itu, penelitian ini menggunakan pendekatan kuantitatif melalui metode statistic deskriptif. Data dikumpulkan melalui telaah dokumen, wawancara dan kuisioner ke $133 \mathrm{KK}$ sebagai responden. Hasil penelitian menunjukkan bahwa peran gender berkaitan dengan peningkatan kesejahteraan masyarakat. Terdapat pola peningkatan kesejahteraan secara informal melalui perubahan mata pencaharian yang pada akhirnya meningkatkan pendapatan warga.
\end{abstract}

Kata kunci: Welfare, Gender, Informalitas

Abstract: Development of Village tourism development model is initiated by the Ministry of tourism and Creative Economy for poverty in rural paved. It's what makes Holy County Government initiative to develop the village into a tourist village Colo based nature tourism. Sunan Muria with fame in Kudus, making the village a Colo is located in the mountains of Muria as one of the tourist destinations that continues to evolve. See this potential, the villagers do tourism management in non-governmental and informal communities through the establishment of supporting tourism, such as taxi, hawkers and street vendors. There is a unique phenomena that are contained in the village of Colo namely management of tours with gender roles. Gender roles are not only happening in the improvement of well-being. Be interesting to examined how gender roles towards the improvement of the welfare of the Community tourism village Colo? to answer that question, this research uses a quantitative approach through descriptive statistics methods. Data were collected through document review, interviews and questionnaire to $134 \mathrm{KK}$ as respondents. The results showed that gender roles related to the improvement of the welfare of the community. There is a pattern of increasing well-being of informally through changes in livelihood and ultimately increase revenue.

Keywords: Walfare, Gender, Informality

\footnotetext{
${ }^{1}$ Dinas Bina Marga Pengairan Energi dan Sumber Daya Mineral, Kabupaten Kudus
}

${ }^{2}$ Jurusan Perencanaan Wilayah dan Kota, Fakultas Teknik, Universitas Diponegoro 


\section{PENDAHULUAN}

Artikel ini membahas mengenai peran gender dalam peningkatan kesejahteraan masyarakat Desa Wisata Colo, kabupaten Kudus terhadap perkembangan pariwisata secara informal berdasarkan sudut pandang kesejahteraan sosial. Besarnya potensi atraksi wisata Desa Wisata Colo yang menyajikan atraksi alam, budaya dan religi ini mendorong masyarakat setempat untuk mengembangkannya sesuai kapasitas mereka. Perkembangan desa wisata secara informal mengawali obyek wisata ini yang pada akhirnya dilegalkan oleh pemerintah melalui penerbitan SK Kepala Dinas Kebudayaan dan Pariwisata No 556/23.01/043C/2014. Upaya informal yang berasal dari kesadaran dan keswadayaan masyarakat ini menjadi menarik untuk dikaji peranannya terhadap peningkatan kesejahteraan masyarakat terutama pada perubahan dan pertumbuhan lingkungan permukiman.

Inspirasi utama penelitian ini bermula dari penelitian yang telah dilakukan oleh Suardana (2006)mengenai peran wanita dalam kegiatan pariwisata. Keterlibatan perempuan dalam sektor pariwisata di Kuta, Bali terlihat dari keterlibatan perempuan terdiri dari 2 sisi yaitu duduk sebagai pengambil kepustusan (pemilik) serta yang terlibat langsung dalam kagiatan pariwisata seperti produksi souvenir, dan penjual souvenir maupun pekerja informal.Temuan ini menjadi penting sebagai dasar pertimbangan penerapan model desa wisata dalam pengembangan pariwisata di Indonesia. Studi tentang perempuan Bali dalam aspek gender dan pariwisata (gender and tourism ) yang dinyatakan oleh (Long dan Kindon, 1997) bahwa ideologi, tipe, dan skala pariwisata sangat menentukan adanya pembagian pekerjaan yang digeluti oleh laki - laki maupun perempuan. Perbedaan pembagian kerja tersebut diterima baik oleh masyarakat.

Desa wisata merupakan model pengembangan pariwisata yang mengintegrasikan atraksi, akomodasi dan fasilitas pendukung dalam suatu struktur kehidupan masyarakat serta menyatu dengan tata cara dan tradisi setempat (Nuryanti, 1993). Keterlibatan masyarakat setempat menjadi komponen penting di dalam model ini (Sutawa, 2012). Desa wisata ini menjadi salah satu program pemerintah melalui kementerian Pariwisata dan Ekonomi Kreatif sejak tahun 1980-an yang salah satu tujuannya adalah untuk mengentaskan kemiskinan masyarakat pedesaan (Permanasari, 2011).

Melihat begitu pentingnya peran pariwisata dalam meningkatkan kesejahteraan, maka perlu adanya upaya penilaian konsep desa wisata ini. Oleh karena itu, penelitian ini menyajikan hasil penlilaian kesejahteraan terutama dalam peran gender peningkatan kualitas hidup masyarakat. Artikel ini menyajikan : (1) sejarah perkembangan Desa Wisata Colo, (2) kondisi sosial ekonomi masyarakat, (3) pengaruh peran gender dalam peningkatan kesejahteraan masyarakat.

\section{METODE PENELITIAN}

Penelitian ini berupa penilaian terhadap kesejahteraan masyarakat yang dipengaruhi oleh peran gender, baik secara langsung maupun tidak langsung oleh keberadaan Desa Wisata Colo, Kabupaten Kudus. Konsep kesejahteraan di dalam penelitian ini merujuk pada pernyataan Yuan, dkk. (1999) yang membahas kesejahteraan dari sudut pandang kualitas hidup, dimana ada tiga bagian yang membentuknya yaitu: (1) viability atau kemampuan ekonomi, (2) livability atau kondisi sosial masyarakat, dan (3) sustainability atau kondisi lingkungan. Meskipun terdapat 3 komponen, penelitian ini memfokuskan pada komponen ke-2 yaitu kondisi kondisi sosial masyarakat berupa pranan gender dalam peningkatan kesejahteraan masyarakat.Untuk mencapai tujuan penelitian berupa penilaian peranan Desa Wisata terhadap pertumbuhan permukiman informal, maka penelitian ini menggunakan pendekatan kuantitatif melalui metode statistik deskriptif. Tiga sumber data digunakan di dalam penelitian ini yaitu (1) kuesioner, (2) wawancara 
terstruktur dan (3) data sekunder berupa laporan dan kebijakan-kebijakan pemerintah terkait dengan Desa Colo. Kuesioner yang terkumpul sebanyak 130 responden dengan target responden adalah rumah tangga warga setempat. Sedangkan untuk informan wawancara sebanyak 5 informan dengan komposisi informasi seperti di jelaskan pada tabel 1. Informan dalam wawancara memilih tokoh masyarakat yang dianggap memahami fenomena lingkungan permukiman. Proses snowballing dilakukan dalam penelitian ini.

Tabel 1. Informan Dan Target Informasi Penelitian

\begin{tabular}{ll}
\hline \multicolumn{1}{c}{ Informan } & \multicolumn{1}{c}{ Target Informasi } \\
\hline BAPPEDA Kab. Kudus & Perencanaan kawasan Periwisata Desa Colo \\
Dinas Pariwisata & Program detail pengembangan pariwisata \\
& Desa Wisata Colo \\
Ketua Paguyuban & Sejarah perkembangan Desa Wisata Colo \\
Ketua Kelompok Sadar Wisata & Perkembangan kesejahteraan masyarakat \\
\hline Sumber: Penyusun, 2015 &
\end{tabular}

Adapun teknik sampel yang digunakan adalah teknik proportionate random sampling. Teknik ini menggunakan pengambilan sample secara acak Arikunto (2002) dengan tingkat kepercayaan yang digunakan adalah 90\% dan kesalahan maksimum sebesar $10 \%$. Kuesioner yang disebar ke masyarakat digunakan untuk mengetahui karakteristik kemampuan ekonomi warga (viable community).

Tabel 2 : Informan Dan Target Kuisioner

\begin{tabular}{ccc}
\hline Wilayah & Jumlah KK & Jumlah Sampel \\
\hline RT 1 RW 1 & 60 & 10 \\
RT 2 RW 1 & 53 & 8 \\
RT 3 RW 1 & 63 & 8 \\
RT 4 RW 1 & 66 & 10 \\
RT 5 RW 1 & 65 & 8 \\
RT 6 RW 1 & 55 & 8 \\
RT 1 RW 2 & 56 & 8 \\
RT 2 RW 2 & 56 & 8 \\
RT 3 RW 2 & 60 & 10 \\
RT 4 RW 2 & 60 & 10 \\
RT 1 RW 3 & 54 & 8 \\
RT 2 RW 3 & 57 & 8 \\
RT 5 RW 3 & 65 & 10 \\
RT 1 RW 4 & 55 & 8 \\
RT 2 RW 4 & 54 & 8 \\
Jumlah & 879 KK & 130 \\
\hline
\end{tabular}

Sumber: Penyusun, 2015

\section{PEMBAHASAN}

Secara geografis, Desa Colo terletak di Kecamatan Dawe Kabupaten Kudus. Pada awalnya, Desa Colo termasuk desa biasa seperti desa lainnya dan masyarakat setempat belum mengerti peran penting pariwisata bagi peningkatan kesejahteraan meraka. Desa ini cukup terkenal karena menjadi peristiratan terakhir Sunan Muria, sehingga menjadi salah satu tujuan utama ziarah umat Islam di Indonesia.

Akan tetapi masyarakat belum menyadari adanya potensi wisata alam. Hingga pada zaman orde baru, secara informal masyarakat membentuk organisasi sadar wisata yang dinamakan "Dewiku". Melihat adanya potensi dan juga partisipasi masyarakat yang baik ini, pemerintah memfasilitasi untuk membentuk sebuah desa wisata secara formal. Pada 
tahun 2013 mulai ditetapkan Desa Colo sebagai desa wisata menurut SK Kepala Dinas Kebudayaan dan Pariwisata No 556/23.01/043C/2014. Faktor - faktor yang menjadikan desa Colo dijadikan sebagai desa wisata adalah adanya obyek wisata religi Sunan Muria, wisata alam dan juga potensi hasil bumi seperti jaruk pamelo, parijoto dan lain - lain.

\section{Kondisi Ekonomi Masyarakat}

Terdapat perubahan perekonomian pada masyarakat Desa Colo, perubahan ini dapat dilihat dari perubahan tingkat pendapatan dan matapancaharian masyarakat Desa Colo. Merujuk pada pernyataan Urtasun dan Gutiérrez (2006) bahwa tingkat pendapatan merupakan salah satu variabel yang dapat digunakan untuk menilai kesejahteraan. Variabel ini dianggap sesuai karena masyarakat dapat merasakannya secara langsung. Terdapat $68 \%$ responden berpendapatan Rp.1.500.000-Rp.2.000.000, mereka yang memiliki pendapatan ini adalah yang bekerja dalam bidang informal dan memiliki tingkat pendidikan setara SMP dan SMA yaitu sebagai tukang ojek, pedagang kaki lima dan persewaan toilet. Hal berbeda dengan 19 responden yang memiliki pendapatan Rp 1.000.000-Rp 1.500.000 yang sebagian besar bekerja pada sektor formal. Penjelasan dapat dilihat pada Gambar 1mengenai persentase tingkat pendapatan masyarakat.

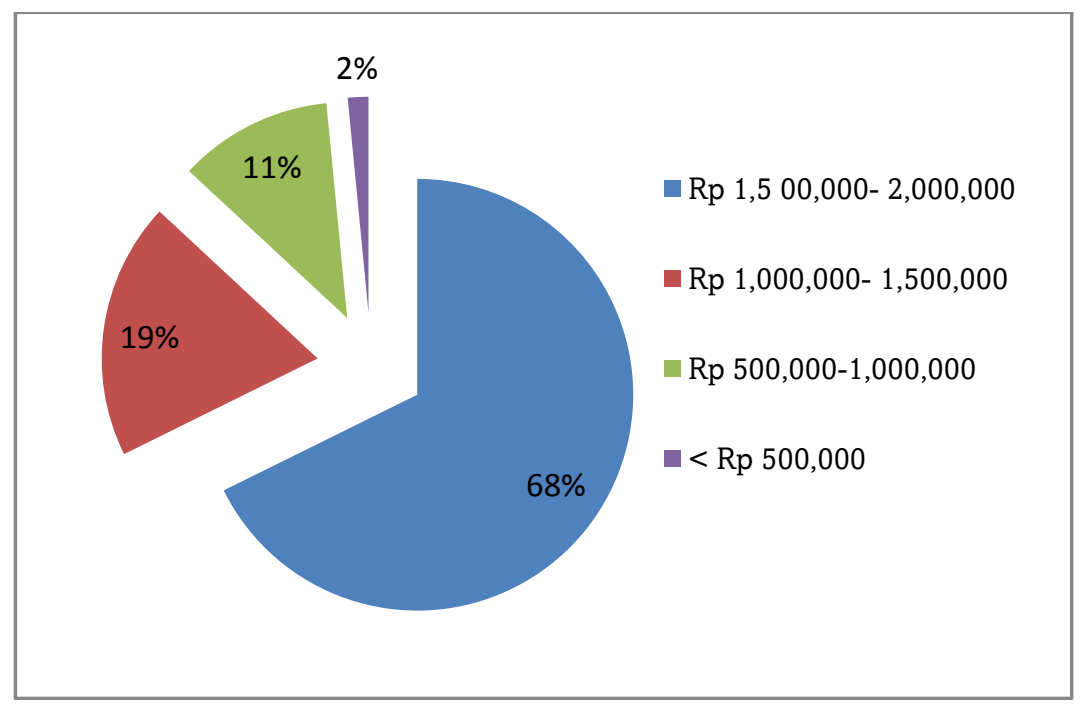

Sumber : Hasil Analisis Penyusun, 2015

\section{Gambar 1. Persentase Tingkat pendapatan Masyarakat}

Dampak adanya peningkatan pendapatan masyarakat berasal dari perubahan mata pancaharian masyarakat. Berdasarkan hasil kuisioner yang dilakukan oleh 130 responden. terdapat $64 \%$ warga yang memiliki matapancaharian tambahan. Sedangkan sisanya yaitu $36 \%$ responden menyatakan tidak memiliki tambahan pekerjaan.Pada Gambar 2 dijelaskan mengenai persentase perubahan matapancaharian warga. 


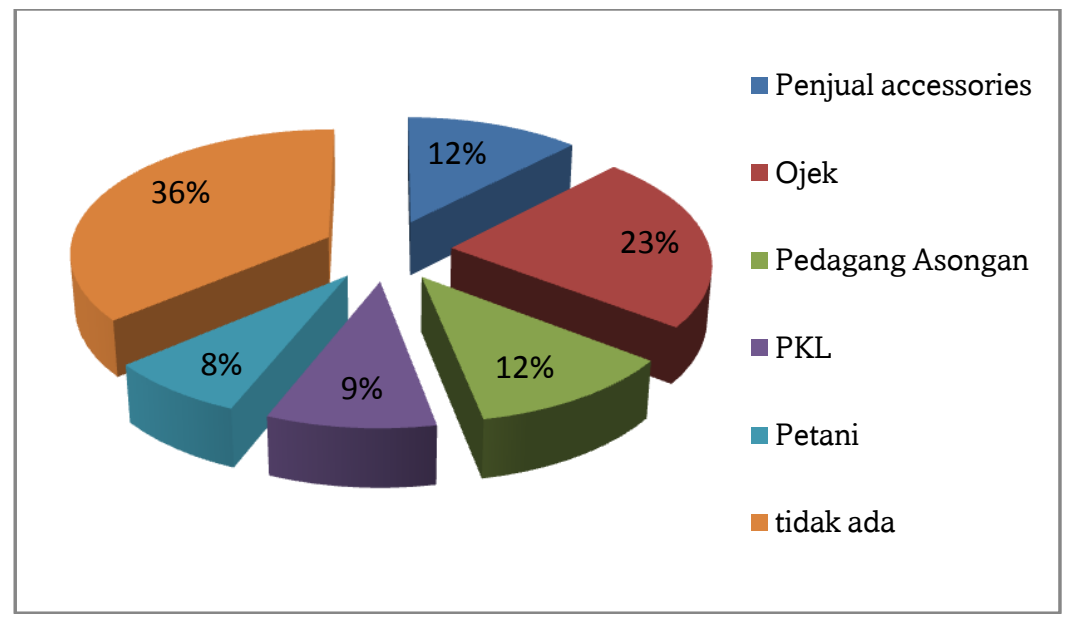

Sumber : Hasil Analisis Penyusun, 2015

\section{Gambar 2. Persentase Tambahan Pekerjaan}

Pertambahan ke lima profesi tersebut berlangsung setelah pembentukan Desa Wisata Colo pada tahun 2006. Penambahan pekerjaan biasanya banyak dilakukan oleh wanita. Dengan adanya penambahan matapancaharian ini akan berdampak pada peningkatan struktur pendapatan. Dimana pendapatan rumah tangga yang sebelumnya hanya bergantung pada satu mata pencaharian saja.

Penambahan pekerjaan ini dapat menghasilkan pendapatan yang setiap harinya bisa mencapai Rp. 100.000,-. Pendapatan tersebut akan meningkat pada hari libur ataupun hari besar lainnya, tergantung dari banyaknya pengunjung yang datang. Dampak penambahan mata pancaharian ini, adalah peningkatan pertumbuhan lingkungan permukiman. Salah satunya adalah semakin meningkatnya PKL dan pertokoan sebagai penunjang pertokoan maka, berpengaruh pula terhadap penggunan lahan.kegiatan pariwisata. Hal ini membuktikan bahwa dengan adanya kegiatan pariwisata dapat meningkatkan peran gender untuk meningkatkan kesejahteraan sari sisi ekonomi, yaitu dengan adanya peran wanita dalam pekerjaan bidang pariwisata yang dapat meningkatkan pendapatan keluarga.

\section{Kondisi Sosial Masyarakat}

Terdapat fenomena unik yang terdapat di Desa Wisata Colo, mengenai bagaimana pengaruh pariwisata terhadap aspek sosial yaitu dengan adanya fenomena pembagian peran gender. Pembagian gender terjadi pada setiap even pariwisata maupun mata pancaharian. Salah satu contoh pembagian gender ini dilakukan pada kegiatan buka luwur. Pada even ini masyarakat sudah terbiasa melakukan gotong royong. Pembagian peran ini dapat terlihat pada peran laki - laki yang berperan dalam even organizer atau berperan dalam perencanaan kegiatan. Sedangkan untuk peran perempuan dalam kegiatan ini lebih banyak dalam bentuk persiapan properti kegiatan adat. Sedangkan peran remaja laki - laki banyak terlibat dalam hal keamanan yaitu dengan membuka jasa penitipan kendaraan. Untuk remaja perempuan adalah ikut membantu dalam menjual makanan dalam kegiatan tersebut.

Berdasarkan hasil Analisis didapatkan bahwa responden yang memiliki tingkatan peran masyarakat yaitu berperan dengan tingkatan pasif dan juga berperan aktif. Berdasarkan tingkat peran pasif berjumlah 65 responden, dengan 16 responden bekerja sebagai PKL, 9 responden pada persewaan toilet, 14 responden pada ojek, 9 responden pada asongan, dan 17 pada bidang pekerjaan Toko. Sedangkan, untuk tingkatan berperan aktif berjumlah 65 responden dengan 7 responden bekerja pada bidang PKL, 5 responden 
sewa toilet, 14 responden pada bidang Ojek, 14 responden pada bidang pedagang Asongan, dan 25 responden pada jasa membuka toko. Berdasarkan hasil analisis tersebut dapat diketahui bahwa, dengan adanya pembangunan Desa Wisata terdapat peran masyarakat terhadap karakteritik pekerjaan Hal ini dapat dilihat dari kerjasama antar warga dalam berbagai kegiatan baik itu even wisata maupun tradisi lainnya tanpa melihat latar belakang pekerjaan. Dalam artian masyarakat akan melakukan peran dalam setiap kegiatan sesuai dengan kemampuan.

Sedangkan untuk peran gender pada kegiatan masyarakat lebih banyak didominasi oleh perempuan. Hal ini dikarenakan tingginya keinginan wanita untuk berperan dalam kegiatan wisata. pada Tabel 3 menjelaskan mengenai distribusi peran gender di dalam kegiatan masyarakat.

Tabel 3 Peran Gender dalam Kegiatan Masyarakat

\begin{tabular}{ccccr}
\hline & \multicolumn{3}{c}{ Peran gender } \\
& & Laki-laki & Perempuan & Total \\
\hline Peran masayrakat & pasif & 33 & 32 & 65 \\
& aktif & 25 & 40 & 65 \\
Total & & 58 & 62 & 130 \\
\hline
\end{tabular}

Sumber : Hasil Analisis Penyusun, 2015

Berdasarkan hasil tersebut didapatkan bahwa responden yang memiliki tingkatan peran masyarakat yaitu berperan dengan tingkatan pasif dan juga berperan aktif. Berdasarkan tingkat peran pasif berjumlah 65 responden, dengan 6responden adalah manula (manusia lanjut usia), 30 responden laki-laki, dan 29 responden perempuan Sedangkan, untuk tingkatan berperan aktif berjumlah 65 responden dengan 2 responden manula, 24 responden laki-laki, dan 39 responden perempuan. Berdasarkan hasil analisis tersebut dapat diketahui bahwa, masayrakat perempuan lebih berperan aktif dalam kegiatan di Desa Wisata yaitu sebanyak 39 responden, karena jumlah mata pancaharian di bidang pariwisata lebih banyak didominasi oleh perempuan daripada laki-laki. Seperti pada jenis pekerjaan PKL,pedagang asongan dan wiraswasta dengan membuka toko. Hal ini dapat dilihat dari pembagian peran antara manula, laki - laki dan perempuan dalam berperan baik pada kegiatan masyarakat maupun pada even pariwisata.

\section{Kondisi Lingkungan Masyarakat}

Selain adanya perubahan kapasitas ekonomi dan sosial, dampak perkembangan desa wisata terhadap kesejahteraan juga berimbas pada perubahan kondisi lingkungan permukiman. Dampak ini juga terjadi pada kawasan Desa Wisata Colo. Perubahan lingkungan banyak terjadi pada kawasan permukiman yang banyak didominasi oleh keberadaan pertokoan, PKL, dan usaha jasa persewaan toilet. Selain didominasi oleh usaha rumahan, kawasan permukiman di Desa Wisata Colo juga banyak dibangun restoran dan juga penginapan yang menawarkan keindahan alam Desa Colo.

Sebelum ditetapkan sebagai Desa wisata, kondisi lingkungan permukiman di Desa wisata Colo masih bersifat tradisional. Hal ini dapat dilihat dari banyaknya warga masyarakat yang memiliki rumah adat dan juga halaman yang luas. Selain itu, masih terdapat lahan hijau di areal permukiman. Setalah ditetapkan sebagai desa wisata, banyak terjadi perubahan di kawasan permukiman. Saat ini sudah mulai berkembang persewaan rumah, pembangunan vila, pembangunan rumah makan dan juga pertokoan. Penyebab perubahan ini disesuaikan dengan kebutuhan wisatawan akan tempat tinggal dan adanya 
perubahan kapasitas ekonomi masyarakat. Pada tabel, menjelaskan mengenai perubahan lahan yang terdapat di Desa Wisata Colo.

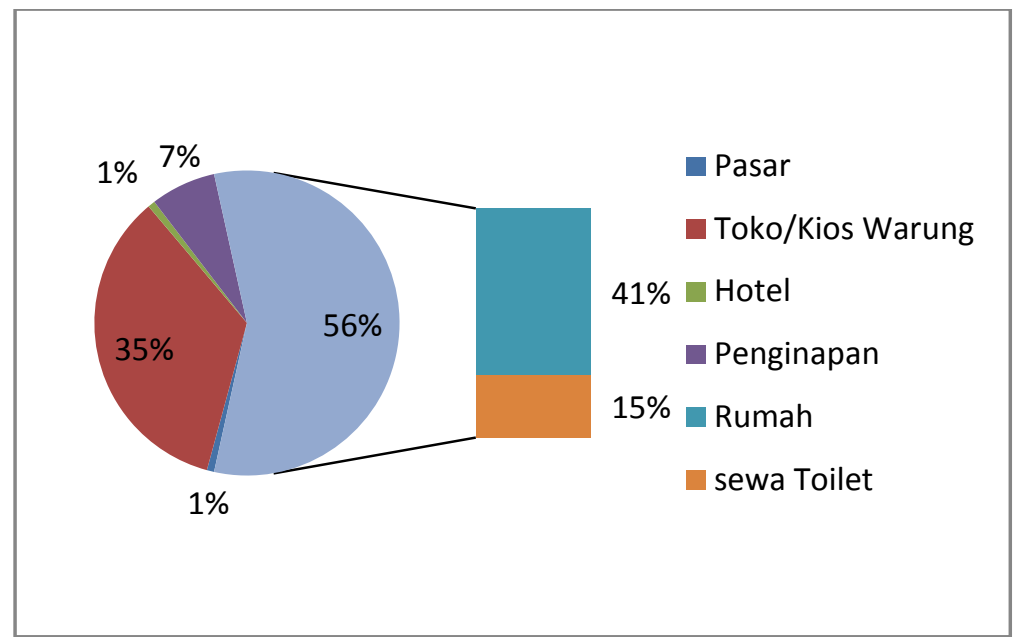

Sumber : Hasil Analisis Penyusun, 2015

\section{Gambar 3 Persentase Perkembangan lahan}

Peran gender tidak hanya terjadi pada aspek ekonomi dan sosial, tetapi peran gender juga terjadi pada kondisi lingkungan. Peran gender berperan dalam kualitas perlindungan lingkungan sekitarnya. Pada tabel, akan menjelaskan distribusi perempuan terhadap kualitas perlindungan lingkungan.Dimana pembagian peran gender di dasarkan pada tingkat kualitas perlindungan lingkungan yaitu tinggi, sedang dan rendah. Sedangkan peran gender yang melibatkan laki-laki, perempuan dan juga manula untuk melihat seberapa besar peran gender tersebut dalam melestarikan lingkungan mereka.

Tabel 4 Kualitas perlindungan lingkungan dan Peran gender

\begin{tabular}{llrrr}
\hline & \multicolumn{3}{c}{ Peran gender } \\
& & Laki-laki & Perempuan & Total \\
\hline \multirow{2}{*}{ Kualitas } & Rendah & 0 & 3 & 3 \\
lingkungan wisata & Sedang & 48 & 51 & 99 \\
& Tinggi & 9 & 19 & 28 \\
\multicolumn{1}{c}{ Total } & & 57 & 73 & 130 \\
\hline Sumber: Hasil Analisis Penyusun, 2015 & & &
\end{tabular}

Berdasarkan hasil analisis tersebut didapatkan bahwa responden yang memiliki tingkatan kualitas perlindungan lingkungan yaitu tingkatan rendah, sedang dan tinggi. Berdasarkan tingkat perlindungan rendah terdapat 3 responden perempuan yang telah berperan. Sedangkan untuk tingkatan sedang terdapat 101 responden dengan peran manula sebesar 5 responden, 45 responden laki - laki dan 51 responden perempuan. Sedangkan untuk tingkat perlindungan tinggi terdapat 26 responden, dengan pembagian 3 responden manula, 9 responden laki-laki dan 14 responden perempuan. Berdasarkan hasil analisis tersebut dapat diketahui bahwa, dengan adanya pembangunan Desa Wisata 
terdapat peran gender dalam melakukan perlindungan lingkungan. Kualitas lingkungan tertinggi disokong oleh perempuan hal ini dikarenakan peran perempuan untuk menjaga kelestarian lingkungan dengan melakukan penanaman pohon di sekitar rumah dan menjaga kebersihan lingkungan.

\section{KESIMPULAN}

Dari penelitian ini diketahui bahwa terdapat pengaruh peran gender di dalam peningkatan kesejahteraan masyarakat. Dalam peningkatan kesejahteraan dapat dari segi ekonomi, sosial dan juga lingkungan. Komponen kesejahteraan yang paling berpengaruh adalah komponen ekonomi dan juga lingkungan. Dimana peran gender berdampak pada peningkatan pendapatan masyarakat. Hal ini dapat dilihat dari banyaknya peran wanita dalam peningkatan pendapatan keluarga melalui perubahan mata pancaharian di bidang pariwisata.

Peran wanita terlihat dari banyaknya yang bekerja sebagai penjual asesories, pedagang asongan,dan juga PKL untuk meningkatkan pendapatan keluarga. Selain berperan dalam peningkatan pendapatan, peran gender juga terjadi pada peningkatan kualitas perlindungan lingkungan. Dimana peran wanita menyokong peningkatan perlindungan lingkungan dengan cara menanam pohon di sekitar tempat tinggal dan menjaga kebersihan lingkungan tempat tinggal. Fenomena ini terjadi secara informal tanpa adanya intervensi dari pemerintah. Akan tetapi di dalam penelitian ini tidak menjelaskan mengenai jumlah jam kerja wanita pada sektor pariwisata dan seberapa besar pendapatan wanita dalam membantu meningkatkan pendapatan keluarga.

\section{DAFTAR PUSTAKA}

Arikunto, S. 2002. Metode Penelitian. PT Bina Aksara. Jakarta,

Long, V. H. \& Kindon, S. L. 1997. Gender and tourism development in Balinese villages. Gender, work and tourism, 91-119,

Nuryanti, W. 1993. Concept, Perspective and Challenges, makalah bagian dari Laporan Konferensi Internasional mengenai Pariwisata Budaya. Gadjah Mada University, Yogyakarta,

Permanasari, I. K. 2011. Pemberdayaan Masyarakat Melalui Desa Wisata Dalam Usaha Peningkatan Kesejahteraan (Desa Candirejo, Magelang, Jawa Tengah). MSi, Universitas Indonesia.

Suardana, I. W. 2006. Pemberdayaan Perempuan Di Kawasan Kuta Sebagai Upaya Peningkatan Kualitas Pariwisata Bali.

Sutawa, G. K. 2012. Issues on Bali tourism development and community empowerment to support sustainable tourism development. Procedia Economics and Finance, 4, 413-422,

Urtasun, A. \& Gutiérrez, I. 2006. Tourism agglomeration and its impact on social welfare: An empirical approach to the Spanish case. Tourism Management, 27, 901-912 http://dx.doi.org/10.1016/j.tourman.2005.05.004.

Yuan, L. L., Yuen, B. \& Low, C. 1999. Quality of Life in Cities-Definition, Approaches and Research. Urban quality of life: Critical issues and options, 1-13, 